\title{
Perjudian Online: Kajian Pidana atas Putusan Nomor 1033/PID.B/2014/PN.BDG
}

\author{
Muhammad Fajrul Falah \\ University of Jember, Indonesia \\ Fanny@gmail.com
}

\section{Fanny Tanuwijaya}

University of Jember, Indonesia

fanny.tanuwijaya@unej.ac.id

\author{
Samuel SM Samosir \\ University of Jember, Indonesia \\ samuelsamosire@yahoo.com
}

\begin{abstract}
Law Number 11 / 2008 on Information and Electronic Transaction (UU ITE) is the regulation concerning on criminal law in addition to the Criminal Code (KUHP). UU ITE is commonly regarded additional regulation of the Criminal Code as a special law (lex specialis) in which Penal Code is deemed as lex generalis. It is based on the principle of lex specialis derogate legi generalis. This article uses legal research to review the decision of District Court in Bandung Number 1033/PID.B/2014/PN.BDG where it comprises legislation and cases. It concludes that the judge is not frugal in applying the principle lex specialis derogat legi generalis in the consideration. This is associated with the indictment of public prosecutor which only prejudges with article 303 paragraph (1) to 2. In contrast, the indictment which does not meet the requirement of a careful, clear, and complete description asserts to become void by law.
\end{abstract}

KEYWORDS: Online Gambling, Criminal Principle, Indictment.

Copyright $\odot 2017$ by Author(s)

This work is licensed under a Creative Commons Attribution-ShareAlike 4.0 International License. All writings published in this journal are personal views of the authors and do not represent the views of this journal and the author's affiliated institutions.

\section{HOW TO CITE:}

Falah, Muhammad Fajrul, Fanny Tanuwijaya \& Samuel S.M. Samosir. "Perjudian Online: Kajian Pidana atas Putusan Nomor 1033/Pid.B/2014/PN.Bdg” (2017) 4:1 Lentera Hukum 31-46.

Submitted: April 21, 2017 Revised: October 12, 2017 Accepted: December 07, 2017 


\section{TINDAKAN PERJUDIAN MELALUI TEKNOLOGI INFORMASI}

Salah satu jenis kejahatan teknologi informasi itu adalah tindak pidana perjudian online. ${ }^{1}$ Di Indonesia perjudian merupakan bentuk kejahatan yang dapat dikenakan sanksi pidana. ${ }^{2}$ Pada hakikatnya perjudian adalah bertentangan dengan Agama, Kesusilaan, dan Moral Pancasila, serta membahayakan bagi penghidupan dan kehidupan masyarakat, Bangsa, dan Negara. ${ }^{3}$ Namun melihat kenyataan dewasa ini, perjudian dengan segala macam bentuknya masih banyak dilakukan dalam masyarakat. Perjudian yang dalam bahasa asingnya disebut (hazardspel) yaitu tiap-tiap permainan yang mendasarkan pengharapan buat menang pada umumnya bergantung kepada untung-untungan saja, dan juga kalau pengharapan itu jadi bertambah besar karena kepintaran dan kebiasaan pemain. ${ }^{4}$ Pada hukum positif Indonesia tindak pidana perjudian dalam jaringan dibedakan dengan tindak pidana perjudi biasa. Tindak pidana perjudian dalam jaringan diatur khusus dalam pasal 27 ayat 2 Undangundang nomor 11 tahun 2008 tentang Informasi dan Transaksi Elektronik sedangkan perjudian biasa diatur secara umum berdasarkan aturan yang terdapat pada pasal 303 KUHP. Perjudian misalnya main dadu, main selikuran, main jemeh, kodok-ulo, roulette, bakarat, kemping keles, kocok, keplek, tambola dan lain-lain, juga masuk totalisator pada pacuan kuda, pertandingan sepak bola dan sebagainya. Tidak termasuk "hazardspel" misalnya : domino, bridge, ceki, peidan sebagainya yang biasa dipergunakan untuk hiburan. ${ }^{5}$

Asas adalah dasar atau sesuatu yang dijadikan tumpuan berpikir, berpendapat dan bertindak. Asas-asas pembentuk peraturan perundang-undangan berarti dasar atau sesuatu yang dijadikan tumpuan dalam menyusun peraturan perundangundangan. Dalam ketentuan Pasal 63 ayat 2 Kitab Undang-undang Hukum Pidana (selanjutnya disingkat KUHP) terkandung Asas Lex Specialis Derogate Lex Generalis yang merupakan asas penafsiran hukum yang menyatakan bahwa hukum yang bersifat khusus (lex specialis) mengesampingkan hukum yang bersifat umum (lex generalis). ${ }^{6}$ Dalam KUHP sudah di atur tentang tintak pidana perjudian tetapi aturan ini bersifat umum (lex generalis) sedangkan di Undang-Undang Nomor 11 Tahun 2008 juga mengatur tindak pidana perjudian yang memiliki unsur-unsur khusus seperti unsur pasal yang terdapat dalam pasal 27 ayat 2 yaitu unsur: mendistribusi-kan, menstransmisikan, dan unsur membuat dapat diaksesnya. Sehingga dapat dikatakan bahwa Undang-Undang Nomor 11 Tahun 2008 merupakan aturan yang bersifat khusus (Lex Specialis) dari KUHP.

Penyusunan surat dakwaan oleh penuntut umum haruslah disusun secara cermat, jelas dan lengkap. ${ }^{7}$ Penuntut umum harus mampu merumuskan surat dakwaan

\footnotetext{
Pasal 27 ayat (2) Undang-Undang No 11 Tahun 2008 tentang Informasi dan Transaksi Elektronik.

Pasal 1 UU No.7 tahun 1974 tentang Penertiban Perjudian.

Konsideran huruf a UU No.7 tahun 1974 tentang Penertiban Perjudian.

R. Soesilo, Kitab Undang-Undang Hukum Acara Pidana (KUHP) (Bogor: Politeia, 1988) hlm. 222.

Ibid.

Peter Mahmud Marzuki, Penelitian Hukum (Jakarta: Kencana Prenada Media Group, 2014) hlm. 141.

Adami Chazawi, Kemahiran \& Ketrampilan Praktik Hukum Pidana (Malang: Media Nusa Kreatif,
} 
berkaitan dengan ketelitian dan kesesuaian antara perbuatan terdakwa dengan ketentuan pidana serta unsur pasal dalam suatu undang-undang yang akan didakwakan. Saat surat dakwaan yang digunakan oleh Penuntut Umum dalam perkara in qasu tersebut tidak memenuhi syarat materiil yaitu cermat, jelas, dan lengkap, maka akan berakibat batal demi hukum atas surat dakwaan tersebut. ${ }^{8}$

Dari uraian di atas tersebut, penulis tertarik untuk menganalisis perkara pidana tentang perjudian online yang telah di putus in kracht atau tetap oleh Pengadilan Negeri Bandung dengan Nomor Perkara : 1033/PID.B/2014/ PN.BDG. Kasus tersebut berawal ketika ketika saksi Ridwan dan saksi Aan Rostiwa sedang melakukan dinas rutin kepolisian menerima laporan dari masyarakat yang menyatakan terdakwa telah melakukan perjudian dalam jaringan tebak angka kemudian kedua saksi melakukan penyelidikan dan setelah mendapat data-data yang akurat dan kemudian dilakukan penangkapan terhadap terdakwa Dendi Oktoyustian bin Ali Sunarja, pada hari Sabtu tanggal 24 Mei 2014 sekitar pukul 10.00 WIB bulan Mei 2014 bertempat di Gang Sukamanah Rt. 07 Rw. 08, Kelurahan Kebonjeruk, Kecamatan Andir, Kota Bandung. Permainan judi tersebut dimainkan dengan cara sebagai berikut: sebelumnnya dengan menggunakan laptop, terdakwa membuat akun dalam website www.tebakmimpi.com/totomini.net (situs tebak angka) dengan nama akun CAVANI dan Password GALATASARAY kemudian terdakwa mendepositkan sejumlah uang minimal Rp. 50.000,- (lima puluh ribu rupiah) ke dalam website tersebut dengan menyetorkan uang tunai melalui rekening BCA an Mario Sanjaya. Setelah akun terdakwa terdaftar dan aktif serta memiliki saldo dalam website tersebut, akun terdakwa dapat menerima pemasangan judi tebak angka tersebut dari orang lain. Terdakwa mendapat keuntungan sebesar 15\% dari setiap angka pasangan serta besar taruhannya yang dimasukkan kedalam website www.tebakmimpi.com/totomini.net yang secara otomatis masuk kedalam website terdakwa.

\section{KESESUAIANPUTUSANNOMOR1033/PID.B/2014PN.BDG YANG MENYATAKAN TERDAKWA BERSALAH}

Perjudian merupakan perbuatan yang dilarang dalam norma hukum yang berlaku di Indonesia. ${ }^{9}$ Bahkan dalam penjelasan UU No.7 tahun 1974 tentang Penertiban Perjudian menyatakan bahwa pada hakekatnya perjudian adalah bertentangan dengan norma Agama, Kesusilaan, dan Moral Pancasila, serta membahayakan bagi penghidupan dan kehidupan masyarakat, Bangsa, dan Negara. Perjudian adalah permainan di mana pada umumnya kemungkinan mendapat untung bergantung pada peruntungan belaka, juga karena pemainnya lebih terlatih atau lebih mahir. ${ }^{10}$

\footnotetext{
2011) hlm 29.

Pasal 143 ayat (3) Kitab Undang-Undang Hukum Acara Pidana.

Pasal 1 Undang-Undang Nomor 7 tahun 1974.

10 Pasal 303 Ayat (3) Kitab Undang-Undang Hukum Pidana.
} 
Sebelum mengurai pengertian perjudian online, penulis akan terlebih dahulu akan menjelaskan tentang "induk" dari perjudian online yaitu cyber crime dan cyber space. Perkembangan teknologi jaringan komputer global atau internet telah menciptakan dunia baru yang dinamakan cyber space. Cyber space merupakan sebuah dunia komunikasi berbasis komputer (computer mediated communication) ini menawarkan realitas yang baru, yaitu realitas virtual (virtual reality). ${ }^{11}$ Dalam menangkap realitas, manusia tidak mungkin berada di 2 atau lebih tempat yang berbeda tetapi cyber space telah melingkupi berbagai sisi dari kehidupan modern dan memungkinkan hubungan yang terjadi tanpa mempermasalahkan jarak, waktu, dan tempat/ruang. ${ }^{12}$ Realitas virtual yang ditampilkan dalam cyber space merupakan suatu kenyataan, fenomena yang kehadirannya, tidak dapat ditangkap atau dipegang dengan tangan, tetapi keberadaanya tidak dapat dielakkan. ${ }^{13}$

Perkembangan cyber space mengubah pengertian tentang masyarakat, komunitas, komunikasi, interaksi sosial dan budaya. Pengertian cyber space tidak terbatas pada dunia yang tercipta ketika terjadi hubungan melalui internet. Menurut John Perry Barlow, cyber space lebih luas dari sekedar hubungan melalui internet. ${ }^{14}$ Cyber Space adalah ruang yang muncul ketika anda sedang menelepon atau membaca buku, ada ruang yang muncul, tetapi ruang yang tercipta itu tidak mungkin untuk berinteraksi secara real-time. Cyber space dalam kenyataannya terbentuk melalui jaringan komputer yang menghubungkan antar negara atau antar benua yang berbasis protokol transmission control protocol/internet protocol. ${ }^{15}$ Dalam sistem kerjanya dapatlah dikatakan bahwa cyber space (internet) telah mengubah jarak dan waktu menjadi tidak terbatas. Internet digambarkan sebagai kumpulan jaringan komputer yang terdiri dari sejumlah jaringan yang lebih kecil yang mempunyai sistem jaringan yang berbeda. ${ }^{16}$

Pada perkembangan selanjutnya kehadiran teknologi canggih komputer dengan jaringan internet telah membawa manfaat besar bagi manusia. Pemanfaatannya tidak saja dalam pemerintahan, dunia swasta/perusahaan, akan tetapi sudah menjangkau pada setiap sektor kehidupan termasuk segala keperluan rumah tangga (pribadi). ${ }^{17}$ Akan tetapi, kemajuan teknologi informasi (internet) dan segala bentuk manfaat di dalamnya membawa konsekuensi negatif tersendiri dimana semakin mudahnya para penjahat untuk melakukan aksinya yang semakin merisaukan masyarakat.

11 Mustofa Hasan, Pengantar Hukum Keluarga (Bandung: Pustaka Setia, 201l) hlm. 217.

12 Ibid, hlm. 97.

Ibid, hlm. 101.

Ibid, hlm. 92.

15 Maskun, Kejahatan Siber (Cyber Crime) Suatu Pengantar (Jakarta: Kencana Prenada Media Group, 2013) hlm. 46.

16 Keny Wiston, The Internet: Issues of Jurisdictio and Controversies Surounding Domain Names (Bandung: Citra Aditya, 2002) hlm. vii.

17 Widyopramono Hadi Widjojo, "Cyber crimes dan Pencegahannya", Fakultas Hukum Universitas Indonesia (2005), 2:2 J Huk Tek hlm. 7. 
Penyalahgunaan yang terjadi dalam cyber space inilah yang kemudian dikenal dengan cyber crime atau dalam literatur lain digunakan istilah computer crime. ${ }^{18}$

Cyber crime didefinisikan sebagai kejahatan komputer, tetapi penggunaan istilah tindak pidana untuk kejahatan computer dalam bahasa Inggris pun masih belum seragam. Beberapa sarjana menggunakan istilah "computer misuse", "computer abuse", "computer fraud", "computer-related crime", "computer-assisted crime" atau "computer crime". Namun para sarjana pada waktu itu, pada umumnya lebih menerima pemakaian istilah "computer crime" oleh karena dianggap lebih luas dan biasa dipergunakan dalam hubungan internasional. ${ }^{19}$ Dari berbagai istilah cyber crime sebelumnya, maka dapat dirumuskan bahwa cyber crime merupakan perbuatan melawan yang dilakukan dengan memakai komputer sebagai sarana atau alat atau komputer sebagai objek, baik untuk memperoleh keuntungan ataupun tidak, dengan merugikan pihak lain. ${ }^{20}$ Dari rumusan cyber crimes tersebut dapat dikatakan bahwa bentuk kejahatan yang dilakukan dengan memakai komputer sebagai sarana/alat dapat dikatakan sebagai kejahatan dalam dunia maya termasuk kejahatan online gambling atau yang biasa disebut dengan perjudian online.

Perjudian dalam jaringan (internet gambling, online gambling atau cyberspace gambling) merupakan perjudian yang dilakukan dengan menggunakan teknologi elektronik yang dapat digunakan untuk mengakses dokumen elektronik maupun informasi elektronik. Dalam dunia maya, perjudian termasuk komunitas komersial terbesar. Pada umumnya metode perjudian yang digunakan cenderung klasik, yakni dengan mempertaruhkan atau sekedar mencoba peruntungan dengan jalan mengikuti instruksi model perjudian yang telah ditentukan. Ada puluhan ribu lebih situs-situs di internet yang menyediakan fasilitas perjudian dari model klasik yang hanya memainkan fungsi tombol keyboard sampai yang sangat canggih yang membutuhkan pemikiran matang dan perhitunganperhitungan adu keberuntung-an. Modus ini menjanjikan banyak keuntungan bagi pemiliknya. Tidak diperlukan lagi perizinan-perizinan khusus untuk membuat sebuah usaha perjudian via internet. Cukup dengan bermodalkan sebuah web dengan fasilitas perjudian menarik, setiap orang dapat memiliki rumah perjudian di internet.

Dalam kasus ini hakim telah menjatuhkan putusan dengan menyatakan terdakwa melakukan tindak pidana sebagaimana di dakwakan oleh penuntut umum dalam pasal 303 ayat (1) ke-2 yaitu "tanpa hak dengan sengaja menawarkan kesempatan kepada khalayak umum untuk melakukan permainan judi”. Berikut unsur-unsur pasal 303 ayat (1) ke-2 berkaitan dengan kasus yang dikaji oleh penulis:
a. Barang siapa;
b. Tanpa izin;
c. Dengan sengaja;

18 Maskun, "Kedudukan Hukum Cyber Crime Dalam Perkembangan Hukum Internasional Kontemporer" (2013) 4:2 J Mas Huk hlm. 3.

19 Mahkamah Agung, Naskah Akademis Kejahatan Internet (Cybercrimes) (Jakarta: Puslitbang Hukum dan Peradilan Mahkamah Agung RI, 2004) hlm. 4.

20 Maskun, supra note 15 hlm. 48. 
d. Menawarkan atau memberi kesempatan kepada khalayak umum untuk bermain judi atau dengan sengaja turut serta dalam perusahaan untuk itu, dengan tidak perduli apakah untuk menggunakan kesempatan adanya suatu syarat atau dipenuhunya sesuatu tatacara.

Secara lengkapnya dapat dijelaskan beberapa keterangan unsur-unsur Pasal 303 ayat (1) ke-2 KUHP yang terdapat dalam putusan Pengadilan Negeri Bandung nomor 1033/PID.B/2014/PN.BDG.

\section{A. Unsur Barang Siapa}

Menurut buku pedoman pelaksanaan tugas dan Administrasi buku II Edisi revisi Tahun 1997 halaman 209 dari Mahkamah Agung RI dan Putusan Mahkamah Agung RI No. 1398K/PID/1994 Tanggal 30 Juni 1995 kata "setiap orang” atau "Hij" disamakan pengertiannnya dengan kata "barang siapa" adalah setiap orang atau siapa saja yang menjadi subjek hukum sebagai pendukung hak dan kewajiban dan dapat diminta langsung pertanggung jawabannya dalam segala tindakan.

Dengan demikian, unsur "barang siapa" mengandung pengertian orang atau manusia sebagai subyek hukum pelaku tindak pidana. ${ }^{21}$ Barang siapa disini adalah setiap orang yang melakukan tindak pidana sehingga perlu dicocokan identitasnya dengan bukti tertulis yaitu Kartu Identitas Penduduk dan sesuai Surat Dakwaan, dimana tindakan tersebut untuk menghindari kesalahan mengenai orang yang dihadirkan di dalam persidangan tersebut atau yang akan diadili di hari itu. Identitas terdakwa tersebut adalah Dendi Oktoyustian bin Ali Sunarja dan dibacakan dihadapan sidang oleh Majelis Hakim perkara in qasu. Setelah identitas terdakwa diperiksa dalam persidangan untuk menghindari terjadinya salah orang (error in persona) cocok dengan identitas sebagaimana tercantum dalam surat dakwaan sehingga dalam perkara ini tidak terdapat kesalahan orang. Pengertian mengenai istilah salah tangkap (error in persona) tidak terdapat dalam KUHAP maupun peraturan perundang-undangan yang lain. Arti dari salah tangkap (error in persona) adalah keliru mengenai orang yang dimaksud atau kekeliruan mengenai orangnya. ${ }^{22}$

\section{B. Unsur Tanpa Izin}

Sifat tercelanya perbuatan menawarkan dan memberikan kesempatan bermain judi, digunakan frasa tanpa izin. Tidak adanya izin, maka perbuatan menawarkan bermain judi menjadi terlarang.

Dalam perumusan perbuatan pidana terdapat unsur melawan hukum yang objektif dan unsur melawan hukum yang subjektif. Unsur melawan hukum yang objektif yaitu unsur melawan hukum yang berkaitan dengan perbuatannya sehingga menjadikan perbuatan tersebut terlarang, apakah melawan hukum dijadikan unsur tersendiri atau tidak. ${ }^{23}$ Sedangkan unsur melawan hukum yang subjektif merupakan

21 Putusan Negeri Bandung nomor 1033/Pid.B/2014/PN.Bdg, Mahkamah Agung, hlm. 21.

22 Marwan, Kamus Hukum (Dictionary of Law Complete Edition) (Surabaya: Reality Publisher, 2009) hlm. 18.

23 Moeljatno, Asas-Asas Hukum Pidana (Jakarta: Rineka Cipta, 2008) hlm. 68. 
melawan hukum yang berkaitan dengan segala sesuatu yang ada dalam diri pelaku, maksudnya adalah suatu perbuatan baru akan menjadi terlarang apabila adanya niat yang buruk dari pelaku perbuatan tersebut. ${ }^{24}$ Unsur tanpa izin diletakkan setelah unsur sengaja dalam rumusan tindak pidana, maka unsur sifat melawan hukumnya disini bersifat obyektif. Sifat melawan hukumnya perbuatannya terletak pada "tanpa izin". Berdasarkan fakta yang terdapat dalam putusan bahwa permainan judi tersebut tanpa izin dari pihak yang berwenang. Dalam putusan Pengadilan Negeri Bandung nomor 1033/PID.B/2014/PNBDG dapat diketahui dari keterangan saksi bahwa bahwa terdakwa bermain judi online tebak angka tersebut hanya bersifat untung-untung saja serta tidak disertai ijin dari pihak yang berwenang.

\section{Dengan Sengaja}

Rumusan tindak pidana, sengaja ditempatkan mendahului unsur perbuatan dan obyek tindak pidana. Berdasarkan hubungan sengaja dengan unsur-unsur lainnya tersebut, maka sengaja disini harus diartikan, bahwa si pembuat menghendaki perbuatan menawarkan atau turut serta kegiatan usaha perjudian. ${ }^{25}$ Maka harus diartikan juga bahwa si pembuat mengehendaki perbuatan menawarkan dan memberi kesempatan dan sadar bahwa perbuatan tersebut dijadikan sebagai pencarian. ${ }^{26}$

\section{Menawarkan Khalayak Umum}

Unsur yang terakhir yaitu berkaitan dengan menawarkan sesuatu pada khalayak umum. Menawarkan atau memberi kesempatan kepada khalayak umum untuk bermain judi atau dengan sengaja turut serta dalam perusahaan untuk itu, dengan tidak peduli apakah untuk menggunakan kesempatan adanya suatu syarat atau dipenuhunya sesuatu tatacara.

Apabila dikaitkan dengan alat bukti, keterangan saksi, maupun keterangan terdakwa. Maka pengertian tindak pidana perjudian kurang sesuai jika hanya dikaitkan dengan pasal 303 ayat (1) ke 2. Tindak pidana perjudian tidak hanya diatur di dalam KUHP tetapi juga di atur dalam UU ITE yang mengatur secara khusus tindak pidana perjudian yaitu dilakukan dengan menggunakan media online. ${ }^{27}$ UndangUndang Nomor 11 Tahun 2008 tentang Informasi dan Transaksi Elektronik mengatur secara khusus tindak pidana perjudian yang dilakukan dengan menggunakan media online. Selanjutnya penulis akan menguraikan unsur-unsur pasal 27 ayat (2) UU ITE untuk mengetahui kesesuaian tindak pidana perjudian yang dimaksud dalam putusan tersebut. Penguraian unsur-unsur tersebut berdasarkan dari alat bukti, keterangan saksi, dan keterangan terdakwa.

\footnotetext{
24 Ibid, hlm. 69.

25 Adami Chazawi dan Ardi Ferdian, Tindak Pidana Informasi dan Transaksi Elektronik Penyerangan Terhadap kepentingan Hukum Pemanfaatan Teknologi Informasi dan Transaksi Elektronik (Malang: Bayumedia Publishing, 201l) hlm. 61.

26 Ibid hlm. 59.

27 Undang-Undang Nomor 11 tahun 2008 tentang Informasi dan Transaksi Elektronik pasal 27 ayat (2).
} 
Berkaitan dengan hal tersebut terdapat unsur yang ditentukan dalam pasal 27 ayat (2). Pertama, setiap orang, yaitu kata "setiap orang" atau "barang siapa" atau "hijj" di unsur Pasal ini menunjukkan bahwa siapa orang (naturlijk persoon) yang semestinya harus bertanggung jawab atas perbuatan pidana. ${ }^{28}$ Bahkan, unsur Pasal "setiap orang" adalah sangat penting dalam hal menentukan siapa yang akan dijadikan terdakwa in qasu. Sedangkan orang yang dimaksud dalam hal melakukan perbuatan pidana tersebut adalah harus dinyatakan bersalah. ${ }^{29}$ Setiap orang disini adalah setiap orang yang melakukan tindak pidana, yang untuk menghindari kesalahan mengenai orangnya, maka identitas terdakwa diperiksa dalam persidangan untuk menghindari terjadinya salah orang (error in persona) yaitu Dendi Oktoyustian bin Ali Sunarja. Dari keterangan saksi Ridwan dan saksi Aan Rostiwa menerangkan terdakwa adalah orang yang dimaksud oleh penuntut umum dalam surat dakwaanya dengan demikian ini telah terpenuhi menurut hukum. Dalam pertimbangan hakim disebutkan bahwa dengan memperhatikan keadaan terdakwa dipersidangan, ternyata bahwa terdakwa dapat memper-tanggungjawabkan atas perbuatannya tersebut, disamping itu berdasarkan fakta-fakta yang terungkap dipersidangan tidak diketemukan adanya alasan-alasan pemaaf dan pembenar yang dapat menghapuskan sifat melawan hukum atas perbuatan terdakwa tersebut.

Kedua, dengan sengaja, yang mana rumusan tindak pidana, sengaja ditempatkan mendahului unsur perbuatan dan obyek tindak pidana. Berdasarkan hubungan sengaja dengan unsur-unsur lainnya tersebut, maka sengaja disini harus diartikan, bahwa si pembuat menghendaki perbuatan menawarkan atau turut serta kegiatan usaha perjudian. ${ }^{30}$ Unsur "dengan sengaja" termasuk dalam unsur kesalahan atau merupakan delik dolus (dolous delict).

Ketiga, tanpa hak, yang dapat dimaknai bahwa unsur tanpa hak adalah tidak mempunyai wewenang atau perbuatannya itu bertentangan dengan hukum dan atau wajib adanya izin dari pihak yang berwenang. Dalam setiap tindak pidana didalamnya mengandung unsur melawan hukum, meskipun unsur tersebut tidak selalu dicantumkan secara tegas dalam rumusan tindak pidana. Dalam pasal 27 ayat (2) menggunakan istilah "tanpa hak" dalam menggunakan unsur melawan hukum. Dari keterangan terdakwa diketahui bahwa terdakwa bermain judi online tebak angka tersebut hanya bersifat untung-untungan saja serta tidak disertai ijin dari pihak yang berwenang. Mendistribusikan dan atau mentransmisikan dan atau membuat dapat di aksesnya informasi elektronik dan atau dokumen elektronik yang bermuatan perjudian.

Terdapat tiga unsur perbuatan yang dilarang dalam pasa 27 ayat (2) yaitu, mendistribusikan dan atau menstransmisikan dan atau membuat dapat diaksesnya informasi elektonik dan atau dokumen elektronik yang bermuatan perjudian. Meskipun antara tiga perbuatan tesebut dipisahkan dengan frasa "dan/atau", tidaklah berarti tiga perbuatan tersebut mempunyai arti yang sama. Logika pencantuman

28 Eddy O.S Hiariej, Prinsip-Prinsip Hukum Pidana (Yogyakarta: Cahaya Atma Pustaka, 2014) hlm. 121.

29 Ibid hlm. 123.

30 Masruchin Ruba'i, dkk, Buku Ajar Hukum Pidana (Malang: Banyumedia Publishing, 2014) hlm. 61. 
perkataan "dan/atau", bahwa antara tiga perbuatan terebut bisa terjadi serentak dalam suatu peristiwa dan bisa juga terjadi salah satu saja. Bila suatu unsur tidak diberikan penjelasan, baik dalam pasal 1 , penjelasan umum maupun penjelasan pasalnya, maka pertama harus ditafsirkan berdasarkan bahasa (gramatikal). Jika menurut bahasa tidak didapat hal yang sesuai, barulah melihat apa maksud pembentuk UU, bila juga tidak ditemukan, barulah menggunakan cara-cara menafsir yang lain.

Mendistribusikan berasal dari kata "distribusi" yang artinya "penyaluran (pembagian, pengiriman) kepada beberapa orang atau kebeberapa tempat". ${ }^{31}$ Menjadi kata kerja "mendistribusikan", yang artinya menyalurkan atau membagikan atau mengirimkan suatu kepada beberapa (banyak) orang atau kebeberapa tempat. ${ }^{32}$ Apabila dihubungkan dengan unsur obyek, maka perbuatan mendistribusikan adalah menyalurkan atau membagikan atau mengirimkan Informasi Elektronik yang isinya memiliki memuatan perjudian.

Akar kata "mentransmisikan" adalah "transmisi" (transmit), yang artinya pengiriman (penerusan), penularan, penyebaran pesan dan sebagainya dari seorang kepada orang (benda) lain. Sementara "mentransmisikan adalah mengirimkan atau meneruskan pesan dari seseorang (benda) kepada orang lain (benda lain). ${ }^{33}$ Sesungguhnya perbuatan mentransmisikandan mendistribusikan mempunyai sifat yang sama. Maksudanya ialah, dengan kedua perbuatan tersebut, suatu informasi menjadi tersalur ke tujuan-penerima informasi. Oleh karena itulah, maka untuk mengukur bahwa kedua perbuatan ini sudah terwujud secara sempurna, adalah dari sudut tersalurnya informasi yang dimaksudkan. Apakah dengan perbuatan yang dilakukan melalui perangkat keras dan perangkat lunak komputer, menurut sistem elektronik teknologi informasi sudah dapat tersalurnya informasi ke penerima informasi. Berbeda dengan kata mendistribusikan dan mentransmisikan yang dirumuskan dalam bentuk kata yang konkret. Perbuatan ketiga "membuat dapat diaksesnya" merupakan kata yang abstrak. Oleh karena sifatnya yang demikian, maka sesungguhnya pengertian mendistribusikan dan menstransmisikan masuk didalamnya. Semua perbuatan, apapun wujudnya apabila menyebabkan tersalurnya informasi elektronik ke penerima informasi dengan menggunakan perangkat komputer, perbuatan itu termasuk dalam perbuatan dapat diaksesnya.

Kata akses artinya jalan masuk, ${ }^{34}$ atau terusan. ${ }^{35}$ Kata akses ini menunjukan bahwa perbuatan itu merupakan perbuatan yang terdapat dalam hal penggunaan teknologi informasi berbasi sistem komputer. Membuat dapat diaksesnya, adalah menjadikan Informasi Elektronik dengan sistem elektronik berbasis komputer dapat diterima oleh (alat) penerima Informasi Elektronik. Dengan kata lain bahwa terdakwa termasuk melakukan perbuatan membuat dapat diaksesnya suatu website dengan cara

31 Pusat Bahasa, Kamus Besar Bahasa Indonesia (Jakarta: Gramedia Pustaka Utama, 2008) hlm. 336.

32 Ibid hlm. 336.

33 Ibid hlm. 1485.

34 Ibid hlm. 30.

35 Emi Zul dan Ratu Aprilia Senja, Kamus Lengkap Bahasa Indonesia (Jakarta: Penerbit Difa Publisher, tth) hlm. 35 . 
membuat akun di website tersut diatas, dan kemudian akun tersebut dapat menerima pemasangan angka dari orang lain.

Menurut penulis, dari uraian-uraian unsur pasal 303 ayat (2) KUHP maupun pasal 27 ayat (2) UU ITE dan dari alat bukti yang ada maka perbuatan yang dilakukan terdakwa sesuai dengan pengertian tindak pidana perjudian dalam jaringan dimana diatur dalam pasal 27 ayat (2) UU ITE, karena dari uraian unsur pasal 27 ayat (2) UU ITE tersebut telah memenuhi dan lebih sesuai dengan fakta yang terdapat dalam putusan. Sebagaimana yang telah penulis sebutkan dalam bab sebelumnya tentang pengertian perbuatan materiil yaitu rumusan yang inti larangannya adalah pada menimbulkan akibat yang dilarang. ${ }^{36}$

Dalam merumuskan delik materiil dimana unsur akibat terlarang itu tidak dicantumkan secara terpisah dengan perbuatan, melainkan telah terdapat pada unsur tingkah lakunya. Artinya dengan merumuskan unsur tingkah lakunya itu, sudah dengan sendirinya didalamnya telah mengandung unsur akibat terlarang. ${ }^{37}$ Dari pembahasan diatas dapat diketahui terdakwa telah melakukan perbuatan yaitu membuat dapat diaksesnya suatu informasi ataupun dokumen elektronik yang memiliki muatan perjudian. Unsur membuat dapat diaksesnya dalam pasal 27 ayat 2 UU ITE merupakan unsur perbuatan yang tidak terpisah dengan unsur akibat terlarang.

\section{KESESUAIAN DAKWAAN PENUNTUT UMUM DENGAN BENTUK TUNGGAL MENGENAI ASAS LEX SPECIALIS DEROGATE LEGI GENERALIS}

Istilah "surat dakwaan" baru dikenal melalui ketentuan pasal 14 huruf d, pasal 140 ayat (1) dan pasal 143 KUHAP. Sebelumnya dalam Het Herziene Inlandsch Reglement (HIR, Staatblad Tahun 1941 Nomor 44) atau perundang-undangan lain (pasal 12 ayat (1) Undang-undang Nomor 15 tahun 1961, pasal 15 undang-undang Nomor 3 tahun 1971) terminologi yang dipergunakan adalah "surat tuduhan" atau "acte van beschuldiging/acte van tenlatelegging". 38 Sedangkan, sebagai perbanding-an kalau bertitik tolak pada ketentuan hukum Belanda maupun negara lainya penganut rumpun sistem Eropa Kontinental surat dakwaan lazim disebut dengan istilah "acte van verwijzing" atau pada ketentuan hukum Inggris dan negara lainnya dalam rumpun penganut sistem Anglo Saxon dikenal istilah "Imputation" atau "Bill of Indictment".

Surat dakwaan ialah suatu surat yang diberi tanggal dan ditandatangani oleh penuntut umum, yang memuat uraian tentang identitas lengkap terdakwa, perumusan tindak pidana yang didakwakan dengan unsur-unsur tindak pidana sebagaimana dirumuskan dalam ketentuan pidana yang bersangkutan, disertai uraian tentang waktu

\footnotetext{
36 Adami Chazawi, Stelsel Pidana, Tindak Pidana, Teori-Teori Pemidanaan dan Batas-Batas Berlakunya Hukum Pidana (Jakarta: Raja Grafindo Persada, 2010) hlm. 126.

37 Ibid hlm. 127.

38 Lilik Mulyadi, Hukum Acara Pidana Normatif, Teoretis, Praktik dan Permasalahannya (Bandung: P.T. Alumni, 2012) hlm. 89
} 
dan tempat tindak pidana dilakukan oleh terdakwa, surat yang menjadi dasar dan batas ruang pemeriksaan di sidang pengadilan. ${ }^{39}$ Pasal 143 ayat (2) KUHAP menentukan syarat surat dakwaan diberi tanggal dan ditandatangani serta berisi nama lengkap, tempat lahir, umur atau tanggal lahir, jenis kelamin, kebangssan, tempat tinggal, agama, dan pekerjaan tersangka. Selain itu juga mencantumkan uraian secara cermat, jelas, dan lengkap mengenai tindak pidana yang didakwakan dengan menyebutkan waktu dan tempat tindak pidana itu dilakukan.

Dari ketentuan Pasal 143 ayat (2) KUHAP tersebut, melalui visi praktisi hukum dalam kelaziman praktik peradilan dikenal adanya 2 (dua) syarat esensial yang harus diperhatikan dalam surat dakwaan, yaitu syarat formil (Pasal 143 ayat (2) huruf a KUHAP) dan syarat materiil (Pasal 143 ayat (2) huruf b KUHAP). Mengenai kedua syarat tersebut, berikut akan di uraikan satu per satu.

Pertama, syarat formil. Mengenai syarat formil ini sesuai dengan ketentuan pasal 143 ayat (2) huruf a KUHAP adalah, "Dicantumkannya identitas tersangka/para tersangka secala jelas dan lengkap terdiri dari nama lengkap, tempat lahir, umur atau tanggal lahir, jenis kelamin, kebangsaan, tempat tinggal, agama, dan pekerjaan tersangka, serta surat dakwaan diberikan tanggal dan ditandatangani oleh jaksa/penuntut umum." Ketentuan syarat formil dalam suatu surat dakwaan diperlukan untuk meneliti apakah benar terdakwa yang sedang diadili di depan persidangan pengadilan negeri adalah sesuai dengan identitas terdakwa dalam surat dakwaan jaksa/penuntut umum. Jadi, dengan diperiksanya identitas terdakwa secara cermat, teliti, dan detail diharapkan tidak terdapat kesalahan mengadili seseorang di persidangan atau kesalahan menghadapkan terdakwa di depan persidangan.

Kedua, syarat materiil. Ketentuan syarat materiil surat dakwaan berdasarkan ketentuan Pasal 143 ayat (2) huruf b KUHAP menentukan, "Uraian secara cermat, jelas dan lengkap mengenai tindak pidana yang didakwakan dengan menyebutkan waktu dan tempat pidana itu dilakukan." Ketentuan tentang syarat materiil surat dakwaan sebagaimana disebutkan di atas tidak menentukan bagai-mana caranya penguraian agar suatu surat dakwaan itu menjadi cermat, jelas, dan lengkap. Mengenai hal ini, pembentuk undang-undang menyerahkan pada perkembangan kebiasaan dalam praktek peradilan, doktrina, dan yuriprudensi.

Dalam menyusun Surat Dakwaan Penuntut Umum harus bersikap cermat/teliti terutama yang berkaitan dengan penerapan peraturan perundang-undangan yang berlaku, agar tidak terjadi kekurangan dan atau kekeliruan yang mengakibatkan batalnya surat dakwaan atau unsur-unsur dalam dakwaan tidak berhasil dibuktikan. ${ }^{40}$ Cermat, didasarkan kepada ketentuan pidana terkait, tanpa adanya kekurangan/kekeliruan yang menyebabkan surat dakwaan batal demi hukum atau dapat dibatalkan atau dinyatakan tidak dapat diterima "niet onvamkelijke verklaard". Selain itu juga perlu terdapat kejelasan yang dalam arti bahwa rumusan unsur-unsur

\footnotetext{
39 Harun M. Husain, Surat Dakwaan Teknik Penyusunan, Fungsi dan Permasalahannya (Jakarta: Rineka Cipta, 1994) hlm, 43.

40 HMA Kuffal, Penerapan KUHAP dalam Praktik Hukum (Malang: UMM Press, 2008) hlm. 206.
} 
delik harus dapat dipadukan dan dijelaskan dalam bentuk uraian fakta perbuatan yang dilakukan oleh terdakwa. ${ }^{41}$ Dengan perkataan lain uraian unsur-unsur atau pengertian yuridis tindak pidana yang dirumuskan dalam pasal yang didakwakan harus dijelaskan/atau digambarkan dalam bentuk fakta perbuatan atau perbuatan materiil yang dilakukan oleh terdakwa. Sehingga dalam uraian unsur-unsur dakwaan dapat diketahui secara jelas apakah terdakwa dalam melakukan tindak pidana yang didakwakan tersebut sebagai pelaku (dader/pleger), sebagai pelaku peserta (mede dader/pleger), atau sebagai penggerak (uitlokker) atau sebagai penyuruh (doen pleger), atau hanya sebagai pembantu (medeplichtige). ${ }^{42}$

Dalam menyusun Surat Dakwaan, Penuntut Umum juga harus mampu menguraikan unsur-unsur tindak pidana dalam undang-undang secara lengkap dalam arti tidak boleh terjadi adanya unsur-unsur tindak pidana yang didakwakan yang tertinggal/tercecer tidak tercantum dalam surat dakwaan. ${ }^{43}$ Lengkap, didasarkan uraian yang bulat dan utuh yang mampu menggambarkan unsur-unsur tindak pidana yang didakwakan beserta waktu dan tempat tindak pidana itu dilakukan.

Pada kasus yang penulis analisis, yaitu Putusan Pengadilan Negeri Nomor: 1033/PID.B/2014/PN.BDG dengan nama terdakwa Dendi Oktoyustian telah didakwa oleh penuntut umum menggunakan dakwaan dengan bentuk dakwaan tunggal yaitu penuntut umum mendakwa dengan Pasal 303 ayat (1) ke 2 KUHP. Dalam bentuk dakwaan demikian, dakwaannya hanya satu/tunggal dan tindak pidana yang digunakan apabila berdasarkan hasil penelitian terhadap materi perkara hanya satu tindak pidana saja yang dapat didakwakan. Dalam dakwaan ini, terdakwa hanya dikenai satu perbuatan saja, tanpa diikuti dengan dakwaan-dakwaan lain.

Dari uraian-uraian unsur pasal 303 ayat (1) ke 2 KUHP maupun pasal 27 ayat (2) UU ITE pada sub bab pembahasan pertama, maka dari alat bukti yang ada dan fakta yang terdapat pada putusan pengadilan perbuatan yang dilakukan terdakwa sesuai dengan pengertian tidak pidana perjudian online dimana diatur dalam pasal 27 ayat (2) UU ITE. Seharusnya penuntut umum mendakwa menggunakan dakwaan tunggal dengan menerapkan pasal 27 ayat (2) Undang-Undang Nomor 11 Tahun 2008 tentang Informasi dan Transaksi Elektronik yang merupakan aturan khusus (lex specialis) dari pasal 303 ayat ke-2 yang merupakan aturan umum (lex generalis).

Adapun syarat-syarat yang dimaksud mencakup tindak pidana lex specialis harus mengandung semua unsur pokok tindak pidana lex generalis. Ditambah satu atau beberapa unsur khusus dalam lex specialis yang tidak terdapat dalam lex generalisnya. Dalam hal ini unsur pokok yang terdapat dalam pasal 303 ayat (1) ke-2 yaitu: a. barang siapa; b. tanpa izin; c. dengan sengaja; d. menawarkan atau memberi kesempatan kepada khalayak umum untuk bermain judi atau dengan sengaja turut serta dalam perusahaan untuk itu, dengan tidak perduli apakah untuk menggunakan kesempatan

$\begin{array}{ll}41 & \text { Ibid hlm. } 206 \\ 42 & \text { Ibid hlm. } 207 \\ 43 & \text { Ibid hlm. } 207 .\end{array}$ 
adanya suatu syarat atau dipenuhunya sesuatu tata cara. ${ }^{44}$ Kemudian penambahan unsur khusus dalam Pasal 27 ayat 2 UU ITE yaitu: a. dengan sengaja; b. tanpa hak; c. mendistribusikan, menstransmisikan, membuat dapat diaksesnya; d. informasi elektronik dan/atau dokumen elektronik yang memiliki muatan perjudian.

Ruang lingkup lex specialis dan lex generalis harus sama. Baik pasal 303 ayat (1) ke-2 maupun pasal 27 ayat (2) UU ITE merupakan aturan pidana. Selian itu terdapat persamaan subjek hukum antara tindak pidana lex specialis dengan subjek hukum lex generalis. Kalau subjek hukum lex generalisnya orang maka subjek hukum lex specialisnya juga harus orang. Subjek hukum kasus yang penulis analisis merupakan orang yaitu terdakwa Dendi Oktoyustian. Hal demikian juga meliputi terdapat persamaan objek tindak pidana antara lex specialis dengan objek lex generalis. Objek tindak pidana dalam pasal 303 ayat (1) ke-2 maupun pasal 27 ayat (2) UU ITE adalah tindak pidana perjudian serta adanya persamaan kepentingan hukum yang hendak dilindungi dalam lex specialis dengan lex generalisnya dan sumber hukum lex specialis harus sama tingkatannya dengan sumber hukum lexgeneralisnya.

Pada dakwaan tunggal seperti diatas, hakim dapat langsung menentukan putusan pidana yang sekiranya sesuai dengan hasil pembuktian di persidangan. Jika dilihat dari pasal yang diterapkan pada dakwaan tunggal di atas, menurut penulis fakta hukum yang terdapat di putusan, alat bukti, maupun keterangan yang didapat dari saksi maupun terdakwa memang telah memenuhi unsur dari pasal 303 ayat (1) ke-2 KUHP dan juga pasal 27 ayat (2) UU ITE, tetapi dengan adanya pasal 63 ayat (2) KUHP yang menyatakan, "Jika suatu perbuatan, yang masuk dalam suatu aturan pidana yang umum diatur pula dalam aturan pidana yang khusus, maka hanya yang khusus itulah yang dikenakan."

Terkait hal itu, penuntut umum maupun hakim harus menerapkan pasal 27 ayat UU ITE. Pasal 27 ayat (2) merupakan lex specialis dari pasal 303 ayat (1) ke-2 KUHP. Pasal 27 ayat (2) UU ITE telah mengatur tindak pidana perjudian yang dilakukan secara online yang tidak diatur pada pasal 303 ayat (1) ke-2 KUHP yang merupakan pasal yang hanya mengatur tidak pidana perjudian biasa (konvensional). Dakwaan dalam bentuk tunggal, sebenarnya mengandung resiko besar karena apabila dakwaan tersebut gagal dibuktikan penuntut umum dipersidangan, terdakwa jelas akan dibebaskan oleh majelis hakim. Ketentuan penutup dalam Undang-undang Nomor 11 Tahun 2008 tentang Informasi dan Transaksi Elektronik menjelaskan dalam Pasal 54 yang berbunyi, “(1) Undang-undang ini berlaku pada tanggal diundangkan. (2) Peraturan Pemerintah harus sudah ditetapkan paling lama 2 (dua) tahun setelah di undangkan undang-undang ini."

Berdasarkan hal tersebut, dapat dikatakan bahwa undang-undang tersebut sudah sah sejak undang-undang itu di undangkan. Dari putusan Pengadilan Negeri Bandung Nomor 1033/PID.B/2014/PN.BDG yang dikaji oleh penulis diketahui bahwa penuntut umum telah menuntut pada tanggal 28 Agustus 2014, yang berarti pada tanggal 
tersebut telah di sahkan Undang-undang Nomor 11 Tahun 2008 tentang Informasi dan Transaksi Elektronik. Penuntut umum dapat dianggap telah mengesampingkan asas lex specialis derogat legi generalis.

\section{KESIMPULAN}

Berdasarkan hasil kajian pembahasan yang telah dipaparkan, maka penulis dapat mengambil kesimpulan bahwa uraian-uraian unsur pada pasal 303 ayat (1) ke-2 KUHP maupun pasal 27 ayat (2) UU ITE dan dari keterangan saksi maupun alat bukti yang ada maka perbuatan yang telah dilakukan terdakwa lebih sesuai dengan pengertian tidak pidana perjudian dalam jaringan sebagaimana diatur dalam pasal 27 ayat (2) UU ITE, karena dari uraian unsur pasal 27 ayat (2) UU ITE tersebut telah memenuhi dan lebih sesuai dengan fakta yang terdapat dalam putusan. Terdakwa terbukti melakukan penerimaan pemasangan dari orang lain untuk akun pada situs web perjudian yang dibuatnya. Penggunaan formulasi surat dakwaan dalam bentuk tunggal sebagaimana dalam Putusan Pengadilan Negeri Bandung Nomor 1033/PID.B/2014/PN.BDG dapat dikatakan sudah tepat, tetapi penuntut umum seharusnya menerapkan Pasal 27 ayat (2) jo Pasal 45 ayat (1) Undang-Undang Nomor 11 Tahun 2008 tentang Informasi dan Transaksi Elektronik untuk mendakwa terdakwa. Dalam merumuskan delik materiil dimana unsur akibat terlarang itu tidak dicantumkan secara terpisah dengan perbuatan, melainkan telah terdapat pada unsur tingkah lakunya. Artinya dengan merumuskan unsur tingkah lakunya itu, sudah dengan sendirinya didalamnya telah mengandung unsur akibat terlarang. ${ }^{45}$

Dari pembahasan dapat diketahui terdakwa telah melakukan perbuatan yaitu membuat dapat diaksesnya suatu informasi ataupun dokumen elektronik yang memiliki muatan perjudian. Unsur membuat dapat diaksesnya dalam pasal 27 ayat 2 UU ITE merupakan unsur perbuatan yang tidak terpisah dengan unsur akibat terlarang. Penerapan pasal 27 ayat (2) UU ITE dikarenakan perbuatan terdakwa telah memenuhi unsur dari aturan tersebut. Berdasarkan uraian yang telah dilakukan terhadap permasalahan maka saran yang dapat penulis berikan adalah seharusnya aparat penegak hukum lebih mengetahui jenis-jenis tindak pidana, baik tindak pidana yang konvensional maupun tindak pidana yang lebih modern. Perjudian sebagaimana diatur dalam KUHP merupakan tindak pidana perjudian yang konvensional, sedangkan tindak pidana perjudian yang diatur dalam UU ITE merupakan perjudian yang dilakukan menggunakan teknologi informasi yang berarti merupakan tindak pidana perjudian dimensi baru yang lebih modern. Seharusnya Penuntut Umum memperhatikan ketentuan Pasal 143 ayat (2) KUHAP terkait syarat formil dan materiil dalam membuat surat dakwaan agar tidak salah merumuskan perbuatan terdakwa. Penuntut Umum juga harus teliti dalam penerapan asas hukum pidana seperti dengan asas lex specialis derogat legi generalis. 


\section{DAFTAR PUSTAKA}

Adami Chazawi dan Ardi Ferdian, Tindak Pidana Informasi dan Transaksi Elektronik Penyerangan Terhadap kepentingan Hukum Pemanfaatan Teknologi Informasi dan Transaksi Elektronik, (Malang: Bayumedia publishing, 2011).

Adami Chazawi, Stelsel Pidana, Tindak Pidana, Teori-Teori Pemidanaan dan BatasBatas Berlakunya Hukum Pidana, (Jakarta: Raja Grafindo Persada, 2010).

Adami Chazawi, Kemahiran \& Ketrampilan Praktik Hukum Pidana, (Malang: Media Nusa Creative, 2011).

Eddy O.S Hiariej, Prinsip-Prinsip Hukum Pidana, (Yogyakarta: Cahaya Atma Pustaka, 2014). Emi Zul dan Ratu Aprilia Senja, Kamus Lengkap Bahasa Indonesia, (Jakarta: Penerbit Difa Publisher, tth).

Harun M. Husain, Surat Dakwaan Teknik Penyusunan, Fungsi dan Permasalahannya, (Jakarta: Rineka Cipta, 1994).

HMA Kuffal, Penerapan KUHAP dalam Praktik Hukum, (Malang: UMM Press, 2008). Keny Wiston, The Internet: Issues of Jurisdictio and Controversies Surounding Domain Names, (Bandung: Citra Aditya, 2002).

Kamus Besar Bahasa Indonesia Pusat Bahasa, (Jakarta: Gramedia Pustaka Utama, 2008). Lilik Mulyadi, Hukum Acara Pidana Normatif, Teoretis, Praktik dan Permasalahannya, (Bandung: P.T. Alumni, 2012).

Maskun, Kejahatan Siber (Cyber Crime) Suatu Pengantar, (Jakarta: Kencana Prenada Media Group, 2013).

Maskun, Kedudukan Hukum Cyber Crime Dalam Perkembangan Hukum Internasional Kontemporer, (2013) 4:2 J Mas Huk,

Maskun, Kejahatan Siber (Cyber Crime) Suatu Pengantar, (Jakarta: Kencana Prenada Media Group, 2013).

Masruchin Ruba'i, dkk, Buku Ajar Hukum Pidana, (Malang: Banyumedia Publishing, 2014).

Marwan, Kamus Hukum (Dictionary of Law Complete Edition), (Surabaya: Reality Publisher, 2009).

Moeljatno, Asas-Asas Hukum Pidana, (Jakarta: Rineka Cipta, 2008). Mustofa Hasan, Pengantar Hukum Keluarga, (Bandung: Pustaka Setia, 2011).

Naskah Akademis Kejahatan Internet (Cybercrimes), (Jakarta: Puslitbang Hukum dan Peradilan Mahkamah Agung RI, 2004).

Peter Mahmud Marzuki, Penelitian Hukum, (Jakarta: Kencana Prenada Media Group, 2014).

Putusan Negeri Bandung nomor 1033/Pid.B/2014/PN.Bdg, Mahkamah Agung.

R. Soesilo, Kitab Undang-Undang Hukum Acara Pidana (KUHP) (Bogor: Politeia, 1988). Widyopramono Hadi Widjojo, Cyber crimes dan Pencegahannya, Fakultas Hukum Universitas Indonesia, (2005), 2:2 J Huk Tek. 
46 | Perjudian Online: Kajian Pidana atas Putusan Nomor 1033/Pid.B/2014/PN.Bdg

This page is intentionally left blank 